\title{
The Importance of Parental Control of Teenagers in Watching Anime with Pornographic Content on the Internet
}

\author{
$1^{\text {st }}$ Zainal Abidin Achmad \\ Department of Communication, FISIP \\ UPN "Veteran" Jawa Timur \\ Surabaya, Indonesia \\ z.abidinachmad@upnjatim.ac.id
}

\author{
$2^{\text {nd }}$ Sjafiatul Mardliyah \\ Department of Non Formal Education, \\ Faculty of Education, UNESA \\ Surabaya, Indonesia \\ sjafiatulmardliyah@gmail.com
}

\author{
$3^{\text {rd }}$ Hervinna Pramitha \\ Department of Communication, FISIP \\ UPN "Veteran" Jawa Timur \\ Surabaya, Indonesia
}

\begin{abstract}
The purpose of this study was to explain the communication experiences between parents and teenagers in providing an understanding of the impact of watching pornographic content on the internet, and to identify the perceptions of parents and teenagers about anime with pornographic content. So that parents will get the best way of controlling. Most parents perceive anime as a cartoon for children, whereas many anime have pornographic content or ecchi elements (nudity and sexual intercourse). It is necessary to disseminate knowledge for parents to control teenagers when watching anime.

Theories used include: stimulus organism response (SOR) theory to analyze perceptions, dialogical ethical theory to explain the process of interpersonal communication between parents and teenagers through dialogue, as well as role theory to explain how parents control teenagers. The research method used is qualitative through in-depth interviews of two groups of informants: teenagers anime buffs and parents.

The results show that parents assess many inappropriate scenes in some anime, because they have ecchi or pornography and are not appropriate for children and teenagers to watch. Teenagers are free to watch anime with pornographic content because it takes advantage of parents' ignorance. Parents and teenagers have different experiences in understanding anime impressions with pornographic content. Limitations of parental knowledge are the main reason in the process of providing an understanding of the impact of watching anime with pornographic content to teenagers. Growing awareness for parental control should be done in three stages: (1) direct control, (2) dialogue to provide an understanding of the impact of watching porn anime, and (3) giving trust when parents and teenagers come to an understanding.
\end{abstract}

Keywords-Anime; Pornographic Content; Internet; Perception; Dialogical Ethics; Parental Control

\section{INTRODUCTION}

The Internet is a network that forms a virtual community, though no human has ever reached that place, but the world is real, because every second and minute humans perform the activity of exchanging messages and data [1]. Internet provides many facilities for human beings, among others: get information; download and upload songs, photos, videos; conduct financial transactions; shop online; interact through social media and so on.

Not only information, all kinds of culture, values, ideology, and pornography will be consumed by using internet. That medium, which is now eroding the future of the child. If the child is not careful using it, it will be fatal [2].

According to a survey of global data web index, Indonesia is a country with the largest number of internet and social media users in Southeast Asia. Internet users in Indonesia, spend time accessing information for 5.5 hours per day. While the use of internet via smartphone or mobile phone about 2.5 hours per day [3]. Access availability is what makes teenagers, freely watching anime on the internet. They love anime from the internet and exchange anime information with friends or relatives.

Anime is a typical Japanese animation, typically characterized by colorful drawings featuring characters in various locations and stories, and aimed at a wide variety of audiences [4]. Anime influenced manga image style, typical Japanese comics [5].

Teenagers watch anime from Youtube and a website featuring anime videos. Also there are some blogs or personal websites that provide the content of anime videos, to make it easier for anime lovers to watch their favorite anime videos. How to watch live on the internet (streaming) or download the video. No need to use a PC or carry a laptop, but simply by using a smartphone, teenagers can watch it. For smartphone owners, there are several mobile applications that are often used by anime lovers to download videos or comics, or watch live on the internet (streaming), such as: "anime Indonesia" and "Otakon". "Otakon" is better known as an application for reading manga [6].

With the support of easy internet access, make teenagers who love anime, free to open a website or personal blogs on the internet and find a variety of pornographic content. Especially with the lack of knowledge and misperceptions of parents about anime, so teenagers can watch anime categories that do not fit their age [7]. 
This research uses informants from New Image Cosplayer (NIC) Surabaya community. Some members and their parents became informants. The Surabaya NIC community was chosen because it has the most number of adolescent members.

This study aims to explain the communication experiences of parents and teenagers in providing an understanding of the impact of watching anime with pornographic content on the internet. Also to identify the perceptions of parents and teenagers about the need to be aware of pornographic content contained in the anime.

\section{RESEARCH METHOD}

This research was conducted with qualitative methods by using in-depth interview techniques [8]. Researchers determine and select informants. The first group of informants, has the following criteria: (1) Incorporated in the Surabaya New Image Cosmetics (NIC) community; (2) Aged 14-17 years; (3) Actively use the internet; (5) Understanding of anime. While the second group of informants is the parents of the teenagers who became informants in the first group.

Based on the criteria for determining the informants, the researchers managed to get 5 teenagers and 5 parents. Three teenagers are high school students and two teenagers are junior high school students. The process of collecting data in this study, conducted by: direct observation of teenage habits while watching anime; interviews with informants; as well as the study of books and articles in journals about anime, pornographic content and parental control. Data obtained from interviews categorized in several sub topics, then analyzed and summarized.

\section{DISCUSSION}

The word anime is the absorption language of English "Animation" and is pronounced as "Anime-shon" [9]. Anime has many genres [10]. Here are some of the most widely known genres, among others: (1) Bishoujo: the main characters are mostly pretty girls; (2) Bishounen: the main characters are mostly cute guys; (3) Harem, a guy figure surrounded by lots of girls; (4) Mecha: a robotic element and war; (4) Magical Girl: magical element; (5) Sentai: a military element, usually telling the real history of PD I \& WW II; (6) Ecchi: shows a bit of vulgar content, not to the sexual stage; (7) Hentai, vulgar and sexually explicit content [11] [12] [13].

The activity of the teenagers in watching anime is motivated by the lack of control and attention from parents, because both parents are working. Parental control difficulties are also caused by the limited knowledge of parents about anime and pornographic content websites. Both of these causes are used teenagers to access the internet freely. The teenagers use anime as a means to express themselves and add association with new friends [14] [15].

Teenagers today are a digital native age group. Meanwhile, their parents are digital immigrants. The impact is a negative potential in cyberspace that threatens children and teenagers are not aware and seriously acknowledged by the parents.
Digital native term for children and teenagers, because they are similar to the native population in the digital world. They are born and grow in the digital age that makes them have a way of thinking, speaking, and acting different from the previous generation which is described as digital immigrant. While the parents referred to as digital immigrants or immigrants who are still trying to adapt in the digital world [16]. As a digital immigrant, parents are required to adapt instantly to the technology used by teenagers.

In this study, the lack of parental knowledge of anime and web sites with pornographic content, due to differences in perceptions between parents and teenagers. Perception is the experience of objects, events, or relationships obtained by inferring information and interpreting messages. Perception is to give meaning to sensory stimuli [17]. Parents perceive that anime is not addressed by parents and is more aimed at children (under the age of youth), so that teenagers are released to watch it. The existence of youtube is perceived as a technological advancement that is more appropriate for use by those who are young, so parents are very rarely interact with youtube. There are even parental informants who expressed ignorance of the terms anime, website and youtube. In addition to their stuttering technology, it also has a shame when viewed as a parent who is familiar with the new media.

The teenagers who are members of NIC Community (New Image Cosplayer) Surabaya utilize internet, website and youtube as a medium to find information and watch their favorite anime. The perception of teenagers against porn anime on the internet, takes place in four stages, namely: (1) Give attention and selection, the teens consciously do a selection of what anime is noticed and what is ignored; (2) Organizing, teenagers make concepts to anime selected through the cognitive or schema and experience; (3) Interpretation, teenagers seek to gain answers and meaning to the concepts and meaning of their experiences while watching anime. (4) Retrieval, is the stage where teenagers seek to regain information about the anime, which has been stored when scanned and organized well.

The process of communication between parents and teenagers in this research is called dialogue. Dialogue is regarded as a way to influence each other between two communication participants; when a participant listens to the other more sensitively, responds politely; or more careful in identifying and expressing the feelings and needs of each participant [18]. Furthermore, the dialogical relationship that exists between parents and teenagers is characterized by a good communication situation, in which each participant listens more sensitively to the disclosure of others' experiences, responds politely, or is more careful in identifying and expressing feelings and the needs of each participant. The dialogue expresses a form of communication that as I-Thou relationship [19].

In an I-Thou relationship, individuals can express and appreciate their own experiences, opinions, ideas, and feelings, as well as being able to appreciate the experiences of others and allow others to express their interests. In I-Thou relationship there is actual dialogue. An "I-Thou" relationship is not self-centered. Each communicator develops an honest, 
open, spontaneous, nonjudmental attitude, and based on equality rather than superiority. In an I-Thou relationship that exists between parents and teenagers, both parties are equally able to express and appreciate their respective experiences.

Instead, there is another relationship called I-It relationship. Other people are regarded as objects to be labeled, manipulated, and altered for the benefit and personal gain of a person. In an I-It relationship that exists between a parent and a teenager, one or both sides are equally selfish. This kind of relationship experiences polarized communication, because each individual feels that meaning is shaped by her / himself and each individual has a specific goal to be achieved.

In a family it takes role sharing. The role within the family is divided into two, namely (1) role of maintenance and (2) role of control. The role of maintenance is done by family members who are responsible in determining the source of the provision of money, food, clothing, and other things needed to maintain households. While the role of control, is a restriction on the choice of behavior of family members by other family members who play a role ensuring the achievement of goals within the family. There are members of the family who are more instrumental in providing guidance, discipline and behavioral restrictions for other family members [20].

Supervision is one part of the control role, which aims to discipline the child as a family member. Supervision plays an important function for family members, especially teenagers, because teenagers are typically identical to unwilling to be controlled and tend to escape from the family. Teenagers have a lot of interaction and socializing with the environment where the control role facilitates the socialization.

\section{RESULTS AND ANALYSIS}

Lots of sites on the internet that provide links to download anime. Previously, researchers have mentioned several commonly known anime genres. In this section the researchers identified several sub genres of anime that were specifically charged with pornography. This identification was obtained through internet search and discussion with informants.

There are at least 10 types of sub-genre Anime with pornographic content: (1) Bakunyuu (Big Boobs) is a hentai genre featuring large-breasted women. Anime of this genre, for example Bakunyuu Maid Kari; (2) Ecchi, is a hentai genre that shows nudity but does not show sexual scenes. Some of the anime genre, namely: Highschool DxD, Queen Blade, and Love Hina; (3) Futanari is a hentai genre that shows a woman with two sexes. Either shemale or hemaprodit; (4) Sometimes the male's genitals only show up at a certain moment but there is also the opposite. An example of anime with this genre is Bible Black; (5) Lolicon, is a genre in which an adult male likes a young girl. Examples of this genre anime is Rizelmine, Moetan, and Kodomo No Jikan; (6) Shotacon, is a genre in which an adult woman likes a young boy and a minor. Anime genre example is A Forbidden Time. (7) The tentacle, is a genre in which women are attacked with monsters or creatures that have tentacles in the shape of male genitals. Then the creature raped the woman with tentacles owned. One of these genre anime, is La Blue Girl; (8) Chikankoui, is anime that tells the life of a chikan or a victim of chikan. Chikan is a person who sexually harasses in a public place, usually done on a train. Anime examples of this genre are 10 Chikan and Midnight Sleazy Train; (9) Doujinshi, is an adult parody (XXX or sexual) of the famous anime or manga in Japan. Some of the anime XXX parodies are: Naruto and Bleach; (10) Yaoi, is the title of the hentai genre that tells about fellow male or gay romance. One of the most famous is Darling or Sadistic Boy; (11) Yuri, is a hentai genre that tells feminine love or so-called lesbian. The famous anime genre is Shoujo Sect: Innocent Lovers and Seikon No Qwaser [21] [22] [23] [24] [25].

The perception of teenagers against porn anime on the internet, based on the difference of electoral stimuli (type of anime genre). There is an interest in searching for characters that are handsome or beautiful figures. There are based on the desire to seek satisfaction by looking at good body shapes (sexy). Some expect to find certain sexual movements. There are teenagers who have the motivation to follow the development of anime to be confident when discussing with peers.

The teenagers do not have a special time and a special place to watch anime. Every opportunity is possible, they use it. In the morning and afternoon can be done in school. If it's night, they do it at home. The bedroom is a favorite choice of places, because it provides solitude and is not disturbed by other family members.

Response of the parents when watching anime with pornographic content shows a tremendous surprise. All parents do not think that anime (which is considered as ordinary cartoons) that teenagers see contains vulgar sexual scenes. However there are parents who allow teenagers to watch as long as they do not imitate the scene in the real world. Parents advise teenagers to pay attention to the genre, rating, and age category of anime, before watching it. Parents agree to block adolescent gadgets from accessing youtube or pornographic (sexually explicit) websites. The parents are aware that blocking such porn anime is very difficult to do, even by youtube itself though. Today, certain title anime can be blocked, tomorrow appear again on youtube with different titles even though the scene is the same.

The way in which the parent will monitor when it comes to pornographic content in the anime, is first with direct supervision. Although in different ways, parents are present near their teenagers when accessing the internet at home. There are parents who are directly close to teenagers and accompany when watching anime. This parent does not forbid but asks a lot about anime, what's the story, what's interesting, on what's good part and so on. This action is done by parents to seek information about the habits of their teenagers while watching anime, as well as the basis for the creation of control rules that will be given to teenagers.

After parents watched and saw the pattern of watching their teenagers, supervision continued with the creation of a warm communication atmosphere, where parents engage in dialogue with their teenagers. Dialogue should be done with face-to-face communication, as the most effective form of 
communication to provide an understanding of the dangers of watching porn anime. This type of communication is considered the most effective way to change attitudes, opinions, or human behavior [26]. The next role of parents is to give their teenagers a trust to access the internet, youtube and anime freely but responsibly.

Currently, parents are required to understand the pros and cons of media and technology use, and seek to upgrade themselves by extending their insight into media and technological developments. Meanwhile, teenagers should be wise in choosing videos and readings that match their age category. Teens have to compromise with the rules that parents make and do not act selfishly

Parental control should not be enough just by direct supervision when children watch anime or accessing youtube, but must also perform other forms of supervision such as referrals and limitations that their adolescent should follow. In order for the control process to take place well, it takes an effective communication between parent and child. If adolescents in the family do not obey the rules, then parental supervision will only be in vain.

\section{ACKNOWLEDGMENT}

The researchers would like to thank: Doctoral Program of Social Sciences, FISIP, Airlangga University; Department of Communication, FISIP, University of Pembangunan Nasional "Veteran" East Java; Department of Non Formal Education, Faculty of Education, State University of Surabaya; and New Image Cosplayer Community Surabaya. Special thanks to: Prof. Dr. Ir. Teguh Soedarto MP; Dr. Falih Suaedi, Drs., M.Si.; Prof. Dr. Musta'in, Drs., M.Si.; Prof. Rachmah Ida, Dra., M.Comms.; Prof. Myrtati Dyah Artaria, Dra., MA., Ph.D.; Prof. Dr. Hotman Siahaan, Drs.; and Novri Susan, S.Sos., M.A., Ph.D.

\section{REFERENCES}

[1] Tamburaka, A. "Literasi Media". Jakarta: PT. RajaGrafindo Persada, 2013.

[2] Abraham, A. "Tersesat di Dunia Maya". Surabaya: PT. Java Pustaka Media Utama. 2010.

[3] Santosa, E. "Raising Children In Digital Era". Jakarta: PT. Elex Media Komputindo, 2015.

[4] Clements, J. “Anime a History”. British Film Institute, 2013.
[5] Lent, J. "Anime History and Cartoon Culture". Globalization of Japanese Popular Media, 1999.

[6] O'Connell, M. "History of Anime". Otakon Program Book, 1999.

[7] Patterson, J. "People's Perception of Anime". Faculty Curated Undergraduate Works. Paper 24. 2015.

[8] Ritchie, J. and Lewis. J. (eds.) "Qualitative Research Practice: A Guide for Social Science Students and Researchers". London: Sage Publications, 2003. (336 pages).

[9] Tracer, J. "Cartoon Culture”. Anime Cartoon Journal, 2013.

[10] Chambers, S. "Anime: From Cult Following to Pop Culture Phenomenon," The Elon Journal of Undergraduate Research in Communications, Vol. 3, No. 2, Elon University, Fall 2012.

[11] MacWilliams, M. "Japanese Visual Culture, Explorations in the World of Manga and Anime”. Armonk: M E Sharpe Inc., 2008.

[12] Napier, S. "Animé from Akira to Princess Mononoke: Experiencing Contemporary Japanese Animation”. New York: Palgrave Macmillan, 2001.

[13] Napier, S. "From Impressionism to Anime: Japan as Fantasy and Fan Cult in the Mind of the West”. New York: Palgrave Macmillan, 2007.

[14] Lamarre, T. "Between Cinema and Anime," Journal Japan Forum, Volume 14, Issue 2, pp. 183-189, 2002.

[15] Denison, R. "Transcultural Creativity in Anime: Hybrid Identities in the Production, Distribution, Texts and Fandom of Japanese Anime." Creative Industries Journal, Volume 3, 2011.

[16] Kompas. "Predator Incar Anak Kita," hal.1 dan 15, 8 Februari 2010.

[17] Cunningham, P. "Transpersonal Sensation and Perception". DOI: 10.13140/RG.2.2.29460.71043, 2015.

[18] Littlejohn, S. and Foss, K. "Theories of Human Communication", $8^{\text {th }}$ ed., Belmont, CA: Wadsworth, 2005

[19] S.A. Beebe, SA.; Beebe, SJ. and Redmond, M. "Interpersonal Communication: Relating to Others". Pearson Education, Inc. 2005.

[20] Le Poire, B. "Family Communication: Nurturing and Control in a Changing World”. California: Sage Publication, Inc., 2006.

[21] Yegulalp, Serdar, "A Brief History of Anime," [Online]. Avalaible: http://anime.about.com/od/animeprimer/a/Brief-History-Of-Anime.htm.

[22] Yegulalp, Serdar, “An Introduction to Anime," [Online]. Avalaible: http://anime.about.com/od/animeprimer/a/What-Is-Anime.htm.

[23] Saka, (The Term in Anime Manga) " "Genre Istilah dalam AnimeManga," [Online]. Avalaible: http://furahasekai.com/2011/09/09/genreistilah-dalam-anime-manga/.

[24] San, Asepu, (10 Types of Anime and Manga Genre) "10 Jenis Sub Genre Anime dan Manga Dewasa," Moshi-moshi [Online]. Avalaible: http://leehans.blogspot.com/2013/06/10-jenis-sub-genre-anime-danmanga.html.

[25] Utomo, Riandanu Madi, (Anime and Cartoon, Whay Do the Fans want to Distict?" Metrotvnews [Online]. Avalaible: http://teknologi.metrotvnews.com/read/2015/09/21/172135/anime-dankartun-mengapa-fans-inginkeduanya-dibedakan.

[26] Forsyth, D. "Group Dynamics". 5 ${ }^{\text {th }}$ ed., Belmont: Wadsworth, 2010. 